\title{
SCREENING ASSESSMENT OF LIGNINOLYTIC AND CELLULOLYTIC ACTIVITY OF BASIDIUM FUNGI STRAINS AND DEVELOPMENT OF STRAINS WITH HIGH POTENTIAL FOR WASTE FERMENTATION CATALYST "BIOVEL-FERMER"
}

\section{СКРИНИНГОВАЯ ОЦЕНКА ЛИГНОЛИТИЧЕСКОГО И ЦЕЛЛЮЛОТИЧЕСКОГО ПОТЕНЦИАЛА ШТАММОВ БАЗИДИАЛЬНЫХ ГРИБОВ И СОЗДАНИЕ НА ОСНОВЕ ПОЛУЧЕННЫХ ДАННЫХ ВЫБОРКИ НАИБОЛЕЕ ПЕРСПЕКТИВНЫХ ШТАММОВ ДЛЯ УСКОРИТЕЛЯ ФЕРМЕНТАЦИИ ОТХОДОВ АПК «БИОВЕЛ-ФЕРМЕР»}

\author{
MASLENNIKOV, Sergey S. ${ }^{* 1}$; SELITSKAYA, Olga V..; SNEGIREV, Dmitry V. ${ }^{2}$ \\ 1 Veles LLC \\ 14/2 Boris Galushkin Str., 129301, Moscow, Russian Federation
}

\author{
${ }^{2}$ Federal State Budgeted Institution of Higher Education "Russian State Agricultural University - Moscow \\ Agricultural Academy named after K. A. Timiryazev" \\ 49 Timiryazev Str., 127550, Moscow, Russian Federation \\ ${ }^{*}$ Corresponding author \\ iris150055@yandex.ru
}

Received in 20 September 2018; received in revised form 08 November 2018; accepted 17 December 2018

\begin{abstract}
RESUMO
Resíduos agrícolas de animais ( $L H C S H)$ causam poluição ambiental severa; é por isso que muitos países têm programas nacionais e regionais para reduzir a pressão negativa desses resíduos sobre o estado ambiental do ambiente. A tarefa real da microbiologia é a busca de métodos alternativos de disposição de resíduos, dentre os quais o mais promissor é a compostagem. Ao contrário de outras formas de utilização do LFA do SZHZH, este método permite obter valiosos biofertilizantes e solos do solo que são mais baratos que os fertilizantes tradicionais. Foi agora estabelecido que, para compostagem sob condições de produção, quando apenas um número limitado de microrganismos é possível, a conversão do substrato inicial é mais eficaz quando vários organismos heterotróficos, em particular fungos com elevado potencial celulolítico e lignolítico, são utilizados como bioativadores. Como os potenciais lignolíticos e celulósicos são as principais características dos basidiomicetos que determinam sua capacidade de biodegradação, a seleção de cepas fúngicas efetivas de "podridão branca" será realizada com base na triagem preliminar de sua atividade ligno- e celulolítica.
\end{abstract}

Palavras-chave: produto biológico, compostagem, capacidade de biodegradação.

\section{ABSTRACT}

Waste from agricultural animals (LHCSH, liquid and solid wastes from agricultural animals) causes severe environmental pollution; which is why many countries have national and regional programs to reduce the negative pressure of these wastes on the environmental state of the environment. The actual task of microbiology is the search for alternative methods of waste disposal, among which the most promising is composting. Unlike other ways of utilizing the LFA (liquid and solid wastes) of the SZHZH (agricultural animals) this method allows obtaining valuable biofertilizers and soil soils that are cheaper than traditional fertilizers. It has now been established that, for composting under production conditions, when only a limited number of 
microorganisms are possible, the conversion of the initial substrate is most effective when various heterotrophic organisms, in particular fungi with high cellulolytic and lignolytic potential, are used as bioactivators. Since the lignolytic and cellulose potentials are the main characteristics of basidiomycetes determining their biodegradation ability, the selection of effective "white rot" fungus strains will be carried out based on preliminary screening of their ligno- and cellulolytic activity.

Keywords: biological product, composting, biodegradation capacity.

\section{АННОТАЦИЯ}

Отходы сельскохозяйственных животных (ЖТО СХЖ) являются причиной сильного загрязнения окружающей среды; именно поэтому во многих странах действуют общегосударственные и региональные программы по уменьшению отрицательного давления этих отходов на экологическое состояние окружающей среды. Актуальной задачей микробиологии является поиск альтернативных методов утилизации отходов, среди которых наиболее перспективным является компостирование. В отличие от других способов утилизации жТО СХЖ этот метод позволяет получать ценные биоудобрения и почвенные грунты, являющиеся более дешевыми, чем традиционные удобрения. В настоящее время установлено, что для компостирования в производственных условиях, когда возможно использование только ограниченного количества микроорганизмов, наиболее эфффективно конверсия исходного субстрата протекает при использовании в качестве биоактиваторов различных гетеротрофных организмов, в частности, грибов, обладающих высоким целлюлолитическим и лигнолитическим потенциалом. Так как лигнолитический и целлюлотический потенциал - основные характеристики базидиальных грибов, определяющие их биодеградационную способность, при реализации предлагаемой работы выбор эфффективных штаммов грибов «белой гнили» будет осуществлен на основании предварительного скрининга их лигно- и целлюлолитической активности.

Ключевые слова: биопрепарат, компостирование, биодеградационная способность.

\section{INTRODUCTION}

Liquid and solid agricultural wastes, including manure, consist of animal excrements and bedding. Bedding is usually made of straw and wood shavings. Both materials are lignocellulose substrates. Biological strains and bacteria consortium (in particular, B. subtilis) activate hydrolysis of the wastes proteins and fermentation of sugars, but lignin, the most difficult polymer to degrade, remains untouched. It is known that lignocellulolytic enzyme producing fungi are quite widespread and belong to ascomycetes and basidiomycetes species. Basidiomycete-induced lignocellulose processes include the activity of the complicated multienzyme complex of cellulases, hemicellulases, and ligninases, which reflects the complexity and integrity of the material degraded. The review of the present data shows that the following mold fungi are used as composting activators: Syncephalasrum recemosum gen. Penicillium, consortium that contains fungi strains Trichoderma, Ergillus, Penicillium and Trametes, etc. Thus, the main biological components of bioproducts, that completely and effectively process lignocellulose wastes, are
basidiomycetes.

Basidiomycetes play a leading role in forest ecosystems, although most basidium macromycetesalso grow in other habitats (meadows, plains, and even deserts). Morphological diversity of basidiomes allows them to be present in all eco-habitats and take part in all stages of organic degradation in forest cenosis. Thus, the main function of basidiomycetes in ecosystems is organic decay at all the stages of its degradation. This capacity allows basidiomycetes to degrade wood substrate, in particular, lignin, which attracts researchers' interest not only in the study of this fundamental process but also in the further development of wood and plant waste processing biotechnologies (Bondartseva, 2008).

White-rot fungi can synthesize a number of extracellular enzymes that take part in modification and degradation of lignin. The most important of them are two heme-containing peroxidases: ligninase (diarylpropaneoxygenase, $\mathrm{H}_{2} \mathrm{O}_{2}$-dependent oxygenase, lignin peroxidase) and manganese peroxidase, which catalase one- 
electron oxidation of aromatic substrates, and one "blue" copper-bearing oxidase - laccase ( $\mathrm{n}$ diphenol: oxygen-oxidoreductase) (Golovleva and Leontievskiy, 1990).

White-rot fungi contain different combinations of main enzymes in their ligninolytic complex. By this feature, they are divided into four groups (although this division is quite conventional and may have exceptions):

- Fungi, synthesizing lignin peroxidase $(\mathrm{LP})$, manganese peroxidase (MnP) and laccase.

- Fungi, synthesizing MnP and laccase.

- Fungi, synthesizing LP and laccase.

- Fungi, synthesizing only LP.

The $1^{\text {st }}$ group includes Phanerochaete chrysosporium (the mostly studied white-rot fungus), Phlebia radiata, Trametes (Coriolus) versicolor.

Mn-peroxidase/laccase group includes Panus tigrinus, Dichomitus squalenes, Rigidoporus lignosus.

Fungi, that synthesize primarily laccase and LP, are Phlebia ochraceofulva, Polyporus pinsitus, Pleurotus florida.

The $4^{\text {th }}$ group includes the most studied fungus - Bjerkandera adusta.

It should be mentioned that there is a special group of white-rot fungi that does not show oxidase activity. Physiology of these fungi is not studied yet. Among them, there are such delignificators as Fomes lignosus and Trametes cingulata (Tuor et al., 1995). Maximal activity levels of the studied strains are presented in Table 1. The obtained data shows that the studied basidiomycetes can be divided into 3 groups. The 1st group contains fungi that show primarily laccase activity of the enzymes of ligninolytic action: Coriolopsis caperata, Pleurotus pulmonarius (Clitopilus prunulus), Steccherinum murashkinskyi, Xerula radicata, Trametes hirsuta. The $2^{\text {nd }}$ group includes such strains as Byssomerulius avellaneus, Trametes versicolor 1666 (given from the collection as Flammulaster limulatoides), Irpicodon pendulus that primarily produces peroxidase). The obtained data agrees with scientific literature data on uneven ligninolytic enzyme production by different basidium fungi genus. It should be noted that ligninolytic enzymes production profiles of the strains Steccherinum murashkinskyi, Xerula radicata, and Irpicodon pendulus were studied for the first time, which complicates their comparison of the mechanism of ligninolysis.

The purpose of the work is to perform screening assessment of the ligninolytic and cellulolytic potential of basidium fungi strains for application in biological products development for processing of liquid and solid agricultural animal wastes into biofertilizers and soil compounds, based on enzyme activator "Biovel-Fermer".

\section{MATERIALS AND METHODS}

Objects of the study were white-rot fungi that perform primary degradation of wood, in particular, Coriolopsis caperata, Pleurotus pulmonarius, Steccherinum murashkinskyi, Trametes hirsuta, Byssomerulius avellaneus, Trametes versicolor, Irpicodon pendulus, and Xerula radicata. All cultures are stored in test tubes in full yeast medium at $4{ }^{\circ} \mathrm{C}$ at the Department of Microbiology and Immunology at RSAU-MAA named after K. A. Timiryazev.

Fungi culture cultivation was performed on agar by the method of static liquid-phase cultivation (by superficial method) with further passage on submerged cultivation.

Superficial cultivation of seed material was done on nutrient medium with initial $\mathrm{pH} 6.0$ of the following composition: $(\mathrm{g} / \mathrm{L})$ : glucose 10.0; peptone 3.0; $\mathrm{KH}_{2} \mathrm{PO}_{4}$ 0.6; $\mathrm{ZnSO}_{4} \times 7 \mathrm{H}_{2} \mathrm{O} 0.001$; $\mathrm{K}_{2} \mathrm{HPO}_{4} \times 3 \mathrm{H}_{2} \mathrm{O} \quad 0.4 ; \quad \mathrm{FeSO}_{4} \times 7 \mathrm{H}_{2} \mathrm{O} \quad 0.0005$; $\mathrm{MnSO}_{4} \times 5 \mathrm{H}_{2} \mathrm{O} \quad 0.05 ; \quad \mathrm{MgSO}_{4} \times 7 \mathrm{H}_{2} \mathrm{O} \quad 0.5$. 0.5 . Cultivation of fungi seed material by superficial method was done in $750 \mathrm{ml}$ test tubes containing ceramic beads and $150 \mathrm{ml}$ of nutrient medium. Bits of epithelium were taken from agar and incubated at $26-28{ }^{\circ} \mathrm{C}$ for $6-8$ days. The test tubes with superficial mycelial film can be stored for 6-8 days at $+4{ }^{\circ} \mathrm{C}$.

Further white-rot fungi growth was performed by submerged cultivation in cone flasks.

Qualitative evaluation of ligninolytic and laccase activity was performed by the express method (Marr, 1979). The strains were cultivated in darkness at $25^{\circ} \mathrm{C}$ in Petri dishes $(90 \mathrm{~mm})$ with the following medium: glucose 10.0; peptone 3.0; $\mathrm{KH}_{2} \mathrm{PO}_{4}$ 0.6; $\mathrm{ZnSO}_{4} \times 7 \mathrm{H}_{2} \mathrm{O} 0.001 ; \mathrm{K}_{2} \mathrm{HPO}_{4} \times 3 \mathrm{H}_{2} \mathrm{O}$ $0.4 ; \mathrm{FeSO}_{4} \times 7 \mathrm{H}_{2} \mathrm{O} 0.0005 ; \mathrm{MnSO}_{4} \times 5 \mathrm{H}_{2} \mathrm{O} \quad 0.05$; $\mathrm{MgSO}_{4} \times 7 \mathrm{H}_{2} \mathrm{O} 0.5$. Ligninolytic enzymes activity was assessed in 1 and 2 weeks of cultivation. 
Near the edge of fungus growing, $5 \mathrm{~mm}$ blocks of mycelium were taken and transferred into the wells of microbiologic plates. After that, solutions of guaiacol $2 \mathrm{ml} / 100 \mathrm{ml} \mathrm{H}_{2} \mathrm{O}$ and $1.0 \%$ syringaldazine in $\mathrm{C}_{2} \mathrm{H}_{5} \mathrm{OH}$ were dropped into the wells. The activity was assessed visually by the intensity of chromatic reactions from "-" - no activity to "+++".

Laccase activity was registered by spectrophotometry by the increase of optical density after adding $0.1 \mathrm{ml}$ of $0.018 \%$ alcohol solution of syringaldazine into reaction mixture $(1.7 \mathrm{ml}$ of phosphate-citrate, $\mathrm{pH} 5.0$ and $0.2 \mathrm{ml}$ of cultural filtrate at the wavelength $\lambda=525 \mathrm{~nm}$ (Leonowicz and Grzywnowicz, 1981). Conventional unit of enzyme activity was taken an increase of optical density in $1 \mathrm{ml}$ of reaction medium per 1 minute.

\section{RESULTS}

The maximal activity level of the studied strains in different media is presented in Table 1. The obtained data shows that the studied basidiomycetes can be divided into 3 groups. The $1^{\text {st }}$ group includes, primarily, fungi that show laccase activity of ligninolytic action: Coriolopsis caperata, Pleurotus pulmonarius (Clitopilus prunulus), Steccherinum murashkinskyi, Xerula radicata, and Trametes hirsuta. The $2^{\text {nd }}$ group includes such strains as Byssomerulius avellaneus, Trametes versicolor 1666 (given from the collection as Flammulaster limulatoides), Irpicodon pendulus with primary production of peroxidase. The obtained data agrees with other scientific data on the uneven distribution of ligninolytic enzymes production by different species of basidium fungi. It should be noted that ligninolytic enzymes production profiles of the strains Steccherinum murashkinskyi, Xerula radicata, and Irpicodon pendulus were studied for the first time, which complicated their comparison of the mechanism of ligninolysis.

The data on levels of enzyme activities, obtained during the studied strains cultivation, in the medium that did not contain straw, were taken as the control. Strains cultivation, performed on straw containing a medium, was defined as the test. The study of laccase dynamics was done by spectrophotometry, using syringaldazine as a substrate.

Before, it was shown that during submerged cultivation of Pleurotus pulmonarius,
Steccherinum murashkinskyi and Coriolopsis caperata on optimized by multifactor test method medium, the levels of laccase activity in culture fluid of Coriolopsis caperata and Steccherinum murashkinskyi were significantly higher than the levels in Pleurotus pulmonariusduring all the period of cultivation. Activity profiles of these fungi were similar, and the maximal level of enzyme activity was observed on the 36th day of cultivation. Still, the level of activity in Coriolopsis caperata was 11 times higher, and in Steccherinum murashkinskyi - 9 times higher than in Pleurotus pulmonarius. Similar dynamics of peroxidase activity was observed in culture fluid of Coriolopsis caperata, it was 10 times higher, and Steccherinum murashkinskyi was 12 times higher than Pleurotus pulmonarius, which shows the nearly similar difference in absolute values of ligninolytic enzyme complex production by these strains.

The dynamics of laccase activity during cultivation of Pleurotus pulmonariusis presented in Figure 1. The analysis of the obtained data allowed the authors to conclude that enzymatic activity profiles in test and control samples were similar and the main difference was in the level of enzyme production. Within 24 days of cultivation, enzyme activity in control and test samples was similar, because there were enough nutrients in the medium. On the $37^{\text {th }}$ day, the maximal activity was observed in both test and control samples, while in test samples the enzyme activity was 3.5 times higher. Probably, it is associated with the fact that within 24 first days the fungi utilized easy sources of carbon and nitrogen (enriched medium) and only after that the process of straw degradation got intensified. During straw degradation in test samples,water-soluble compounds were synthesized, which were used as a source of carbon and nitrogen. Possibly, this is accompanied by the synthesis of straw degradation products, which induce enzyme biosynthesis by the strain.

Dynamics of laccase activity during cultivation of Coriolopsis caperata, Steccherinum murashkinskyi, and Trametes hirsuta is presented in Figures 2-4. The presented data shows inhibition of straw degradation by straw components or products of its degradation approximately by 18,2 and 13 times for Coriolopsis caperata, Steccherinum murashkinskyi and Trametes hirsuta strains, respectively, during the cultivation.

The most interesting data were obtained 
during cultivation of Xerula radicata. Under both options of cultivation, laccase activity did not differ significantly. Absolute values of laccase activity did not differ either, which allowed the authors to suggest that peroxidases play the main role in the process of delignification.

Based on the obtained data, it was concluded that activity profiles are similar and differ by the level of enzymatic activity. It should be noted that in this case the opposite tendency is observed, enzymatic activity in the control samples was higher by $2-18$ times than in the test samples. This can be associated with the compounds that are synthesized during the process of straw destruction. They inhibit the production of laccase enzyme by Coriolopsis caperata, Steccherinum murashkinskyi, and Trametes hirsuta.

The data of significant interest was obtained by the comparison of laccase dynamics activity in the test samples of Coriolopsis caperata and Pleurotus pulmonarius. Laccase inhibition in Coriolopsis caperata by the compounds, that were synthesized during straw biotransformation, was observed. The rate of inhibition was 4 times higher. The opposite was seen at the cultivation of Pleurotus pulmonariuslaccase activity is induced by the products of straw biotransformation. Thus, at the moment of maximal enzymatic activity, shown by Pleurotus pulmonarius and Coriolopsis caperata, the levels of activity differ by 7.5 times. Still, the profiles of activity of both fungi species are similar.

Cultivation of Byssomerulius avellaneus, Trametes versicolor 1666 (Flammulaster limulatoides) and Irpicodon pendulus, which were included into the $2^{\text {nd }}$ group with lower enzymatic activity during surface cultivation, showed that straw containing medium significantly increased laccase activity.

The obtained data showed that during the cultivation of Byssomerulius avellaneus in straw containing a medium, laccase biosynthezis induction was observed, its activity increased by 195 times. A similar tendency was seen during basidiomycete Irpicodon pendulus cultivation, and its activity increased by 27.5 times. The biggest difference in enzymatic activity during cultivation in the enreached nutrient medium was observed in Trametes versicolor, which was 233 times higher.

Thus, the activity of fungi from the $1^{\text {st }}$ group, which had a high level of enzyme production during submerged cultivation and high level of laccase production during surface cultivation, was inhibited by the products of straw degradation or by straw components, which appeared during sterilization of the substrate in an aqueous medium. However, basiomycetes with a low level of laccase biosynthesis from this group at submerged cultivation and with high level at submerged cultivation in straw containing medium (Pleurotus pulmonarius) were similar to the fungi from the $2^{\text {nd }}$ group, where the enzyme activity increased in the presence of straw.

Apart from laccase, ligninolytic basidiomycete enzymatic complex contains peroxidase that plays an important role in complex biopolymer transformation. The scientific literature review showed that the genes, encoding peroxidases, were present in all the genomes of the studied basidiomycetes. It is known that basidiomycetes synthesize a wide range of peroxidases, like ligninperoxidase, Mnperoxidase, versatile peroxidase, etc. Peroxidase activity was identified by two methods: classic test by 2,2'-azino-di-[3-ethylbenzothiazoline sulphonate] (ABTS) as a substrate in the presence of peroxide and modified test for polyfunctional peroxidases by ABTS substrate in the presence of peroxide and $\mathrm{Mn}^{2+}$.

General dynamics of peroxidase activity during cultivation of the studied strains were similar to the observed laccase activity.

Peroxidase activity profiles during cultivation of Pleurotus pulmonariusin the enriched nutrient medium in the presence of straw and in the absence of straw were similar. During the first 16 days, peroxidase activity in control and test samples was similar, and then significantly increased in the test samples. The maximal activity was registered on the $36^{\text {th }}$ day of the cultivation, and the activity was 9 times higher in the test samples than in the control ones.

When the fungi were cultivated in a poor nutrient medium, significant differences in activity levels were observed starting from the $14^{\text {th }}$ day. Maximal difference in activity levels between the control and the test samples was registered on the $39^{\text {th }}$ day when the activity in test samples was maximal and exceeded the activity in control samples by 29 times. It should be noted that during surface cultivation in a poor nutrient medium, a sharp increase of peroxidase activity was registered on the 16th day, and it remained high during all the period of cultivation. 
During the first 14 days of cultivation in an enriched nutrient medium, the activity in control and test samples were similar, and then a quick increase of activity was registered in the control samples, reaching the maximal values on the $45^{\text {th }}$ day (in the control sample the activity was 18 times higher).

Absolute values of peroxidase activity during cultivation of St. murashkinskyi were significantly higher (by 4 and 200 times) than in Coriolopsis caperata and Pleurotus pulmonarius, which allowed the authors to consider peroxidases as dominant enzymes in lignocellulotic material degradation by this strain, although degradation products exerted a significant inhibitory effect.

Comparison of peroxidase activity dynamics of the studied fungi showed that absolute values of enzymatic activity in Pleurotus pulmonariuswere 22.5 times higher than in Coriolopsis caperata during cultivation in the enriched nutrient medium.

Unlike the dynamics during cultivation of the previous strains, where there were no differences during the first 15-20 days of cultivation between the dynamics of activity in the presence and absence of straw, in Trametes hirsuta fungi significant change was observed between the test and control samples during the first 15 days and on the $10^{\text {th }}$ day, when maximal activity was 2.4 higher than in the control samples. Absolute values of peroxidase activity during cultivation of Trametes hirsuta was close to the values in St. murashkinskyi strain. Further cultivation of peroxidase activity was high in both cases during all the period of cultivation. The obtained data indicated on high potential of Trametes hirsuta for development of biological products for processing of hard degrading fraction of manure.

The study of activity dynamics in basidiomycete Xerula radicata showed inhibiting the action of straw and its components on the peroxidase production. Enzymatic activity during cultivation in straw containing medium decreased by 2 times.

The obtained data showed that both laccase and peroxidase biosynthesis activation was observed during cultivation of Pleurotus pulmonariusin straw containing medium. Cultivation of Coriolopsis caperata, St. Murashkinskyi, Trametes hirsuta, and Xerula radicata strains showed laccase and peroxidase inhibition in the straw-containing medium.

Fungi from the $2^{\text {nd }}$ group had the highest peroxidase activity in comparison with laccase activity level. Thus, Byssomerulius avellaneus did not show peroxidase activity in the control samples, but during cultivation in straw containing medium the activity was 114 units by the $45^{\text {th }}$ day and by the $70^{\text {th }}$ day the activity increased by 1.5 times more. Trametes versicolor and Irpicodon pendulus increased by 266 and 68 times, respectively.

The study of versatile peroxidase dynamics was performed using ABTS and $\mathrm{Mn}^{2+}$ as substrates in the presence of hydrogen peroxide. Similar to peroxidase and laccase activity, the inhibition of versatile peroxidase activity during cultivation of Coriolopsis caperata, Trametes hirsuta, and Steccherinum murashkinskyi was observed. The increase of versatile peroxidase activity (VP) was observed during cultivation of Pleurotus pulmonariusin straw containing medium. The increase of VP activity in Pleurotus pulmonariuswas by 1.8 times. In Coriolopsis caperata, Trametes hirsuta and the Steccherinum murashkinskyi samples enzyme production decrease were by $37.8,1.5$, and 1.8 times, respectively.

The lowest sensitivity of PA in Trametes hirsuta to inhibiting the action of straw indicated on the high potential of this basidiomycete for development of biological products for processing of hard degrading fraction of agricultural wastes.

In Xerula radicata the activity of VP was lower during cultivation in straw containing medium than in the control samples during cultivation for 35 days. However, during further cultivation enzymatic biosynthesis activation was observed.

In the $2^{\text {nd }}$ group of strains, the tendency towards enzyme production increase in straw containing medium remained. The most significant change was observed in the activity of Trametes versicolor fungi, it was higher by 1090 times. The increase of VP activity during cultivation of basidiomycetes Byssomerulius avellaneus and Irpicodon pendulus in the poor nutrient medium was by 401 and 17 times and in enriched nutrient was by 542 and 6 times, respectively.

It is known that ligninolytic complex includes not only enzymes that transform lignin, but also concomitant enzymes that maintain ligninolytic enzymes functioning. One of the 
enzymes that catalyze hydrogen peroxide synthesis is aryl-alcohol oxidase that maintains the reactions catalyzed by peroxidases.

Comparison of aryl-alcohol oxidase activity dynamics during cultivation of Pleurotus pulmonarius, Coriolopsis caperata, and Trametes hirsuta showed that in both cases during cultivation the activity was higher in the test samples than in the control samples, which indicated on the increased need in hydrogen peroxide during fungi growth in straw containing a medium. This can be associated with both increase of enzymatic biosynthesis, that utilize hydrogen peroxide as a substrate, and intensification of non-enzymatic processes of lignocellulotic substrate biotransformation. Comparison of peroxidase and aryl-alcohol oxidase activity dynamics showed that the peak of peroxidase activity was preceded by the peak of aryl-alcohol oxidase activity, which indicated on the close association between not only catalytic enzyme cycles, but also their biosynthesis.

There were 2 peaks of activity on the activity profiles of both strains during cultivation in different media. The $1^{\text {st }}$ peak was observed on the $8-15^{\text {th }}$ days, and the $2^{\text {nd }}$ peak was registered at the end of cultivation. The maximal difference in activity levels in the control and test samples in Pleurotus pulmonariuswas higher by 18 times, for Coriolopsis caperata - by 11 times on the $14^{\text {th }}$ day, and for Trametes hirsuta - by 13 times on the $8^{\text {th }}$ day.

Since the levels of aryl-alcohol oxidase in both fungi were similar, it can be suggested that the fungi produced the nearly equal amount of peroxide enzymes. However, as it can be seen by the data from previous studies, the level of peroxidase activity in Coriolopsis caperata is lower than in Pleurotus pulmonarius, which is, probably, associated with sorption of these enzymes by straw, and, consequently, with the underestimated activity level of this enzyme in Coriolopsis caperata. It can also be suggested that there are differences in mechanisms of biotransformation of lignocellulose materials, in particular, in the presence of non-enzymatic stage within this process.

During the cultivation of the studied strains, the level of enzyme production was higher in the test samples than in the control ones during all the period. This indicated on the presence of ligninolytic activity inducers in the straw containing a medium that acted as substrates for ligninperoxidases. It should be noted that induction of enzyme production for different strains differed by 8-425 times and did not depend on the group, where they belonged. The highest activity increase was observed in Steccherinum murashkinskyi in comparison with the control samples, and the lowest activity was observed in Pleurotus pulmonarius.

Straw biotransformation monitoring was performed on the $29^{\text {th }}$ and $47^{\text {th }}$ day of cultivation. The controlled parameters of straw biotransformation process included lignin, cellulose and hemicellulose content, ash content and mycelium mass. Identification of watersoluble compounds in the samples of biotransformed straw was not reasonable because the majority of its mass contained in the cultural fluid.

The obtained data showed that the straw mass reduction during biotransformation by the studied basidiomycetes was on average $20 \%$, despite the significant difference in the levels of enzymatic activity of ligninolytic complex enzymes.

The data presented in Table 2 shows that on the $47^{\text {th }}$ day lignin reduction did not increase significantly in comparison with the 29th day. The highest lignin reduction was observed in Pleurotus pulmonarius samples, where the reduction increased by 1.39 times. The reduction of straw in all the fungi samples on the 29th day in comparison with the 47th day did not change significantly, except in Trametes versicolor and Cerrena maxima strain samples, where the reduction level was 2.2 and 1.3 higher, respectively.

Significant reduction of hemicellulose by Pleurotus pulmonarius, Coriolopsis caperata and Trametes maxima strains was observed on the $29^{\text {th }}$ day. However, further hemicellulose degradation was more intensive, and by the $47^{\text {th }}$ day, its level became similar to other fungi. The strains Trametes versicolor, Byssomerulius avellaneus,and/rpicodon pendulus degrade straw hemicellulose well. However, they consume cellulose less intensively. It is evident that the effectiveness of this process depends on the range of enzymes synthesized by the studied basidiomycetes.

Xylolysis index is the key parameter in the process of lignocellulotic materials degradation that shows the ratio of the utilized cellulose to the summary cellulose and lignin degradation by 
fungi. This coefficient allows the researchers to estimate what consumption is bigger: cellulose or lignin. The obtained results analysis showed that the studied fungi belonged to the species of white-rot that equally well degrades lignin and cellulose, causing significant mineralization of plant material.

The obtained data, presented in Table 2, showed that during surface cultivation more cellulose was utilized than lignin since xylolysis index was $>0.5$. During cultivation, the xylolysis index reduced with time, but still remained $>0.5$. This indicated on the fact that fungi first consumed nitrogen and carbon from the medium, and when their content was reduced, they started degrading a more complicated source of carbon straw cellulose. Only after that, at the stage of secondary metabolism, these strains began to utilize lignin more intensively by an enzymatic method, i.e., producing ligninolytic enzymes.

The dynamics of enzymatic activity for all the studied cultures had two peaks. The peak of second order activity for all the strains was observed on the $29-30^{\text {th }}$ day of the cultivation, which indicated on the activation of secondary metabolism, accompanied by the cells autolysis, intracellular phenoloxidases release and activation of other enzymatic systems (for example, intracellular tyrosinase) that can oxidize phenolic compounds, including pyrocatechin, which is a standard substrate for laccase activity identification.

Based on the obtained data on the lignin content reduction and laccase activity dynamics, it can be suggested that there is no direct correlation between these parameters. However, the high level of this enzyme activity indicates its importance in the processes of delignification. The results of the present study confirm other research data on the key role of laccase in the process of lignin-carbohydrate complex degradation by the fungi (Babitskaya, 1991; Ernakova, 1972). Lignin molecule residues exert high reactive capacity due to their propylphenolic radical groups and can be very dangerous for any biological system, in particular, for microorganisms' cells. It can be suggested that laccase with its capacity to polymerize low molecular aromatic compounds induces oxidative condensation of lignin molecules residues. It leads to the synthesis of high molecular complexes with the inclusion of protein nitrogen by nucleophilic mechanism (Orlov et al., 1969; Paszczynski et al., 1988).
Monitoring of straw biodegradation process was performed in the same way as during surface cultivation on the $29^{\text {th }}$ and $47^{\text {th }}$ day, but additionally, water-soluble compounds of cellulose were identified during solid-phase cultivation. It was done because water-soluble compounds were contained in the concentration higher than in cultural liquid, where it was less than $3 \%$. During solid-phase cultivation it is impossible to separate fungi mycelium from straw, for this reason, the whole lab tube content was dried and fined for further identification of substances content (Figure 5).

The data obtained during straw biotransformation monitoring at the solid-phase cultivation of the studied basidiomycetes were summarized in Table 3 . The results showed that on average the fungi from the $1^{\text {st }}$ group utilized up to $50 \%$ of the straw mass, which confirmed their high delignification potential, and fungi from the $2^{\text {nd }}$ group and Xerula radicata only up to $10-25 \%$.

During the cultivation, basidiomycete strains degraded the plant substrate in similar grade. After 47 days maximal substrate reduction was $31.8 \%$ in $T$. hirsuta, $32.7 \%$ in T. maxima, $32.2 \%$ in Coriolopsis caperata and $31.6 \%$ in Pleurotus pulmonariussamples. Hence, among the studied strains, $T$. hirsuta had the highest potential in the development of biological products for degradation of hard degrading components of agricultural wastes. The efficiency of other strains was lower. Minimal values of straw mass reduction were observed in Trametes versicolor samples, and it was equal to $8.3 \%$.

The high potential of $T$. hirsuta in development of biological products was confirmed by the data on lignin reduction in straw during the studied period. This strain showed the highest lignin reduction level equal to $38.9 \%$. The rest strains showed a lower reduction level: $35.4 \%$ in T. maxima and $35.9 \%$ in Pleurotus pulmonarius samples. The lowest reduction level of lignin was observed in Trametes versicolor and Xerula radicata samples, it was 8.7 and $11.5 \%$, respectively. However, in these basidium fungi samples, the reduction of water-soluble celluloses was more than $60 \%$. In Trametes versicolor strain sample they were completely utilized. Hemicellulose reduction level was higher than cellulose reduction level in Xerula radicata and Trametes versicolor samples by 5-6 times, which indicated on the high cellulolytic activity of these strains.

The obtained data showed the high 
degrading activity of the studied strains towards lignocellulotic materials and highly selective action on lignin. The comparison can be made with other research data on white-rot fungi. For example, Pl. eryngii, $P h$. radiata and Ceriporiopsis subvermispora reduced wheat straw mass by $20-30 \%$ on the 60th day of solidphase fermentation. Ph. chrysosporium degraded up to $45 \%$ of the substrate in the same period (Galliano et al., 1991). The same fungus mineralized the majority of lignin content (up to $12 \%$ ) by the end of cultivation. Thus, it can be concluded that ligninolytic activity of nearly all the studied strains, except for Trametes versicolor and Xerula radicata, was high. Whilst, $T$. hirsuta has the highest potential in the development of the biological product for processing of agricultural wastes. This strain showed the highest results by a number of parameters, including lignin and cellulose content reduction during solid-phase cultivation.

The analysis of the data on the content of main straw components (cellulose and lignin) before and after solid-phase fermentation of basidiomycetes on this substrate and on the straw mass reduction during the fermentation (Table 3) allowed the authors to estimate cellulose and lignin mass reduction and calculate the Ic index. The Ic index is an important characteristic of wood-degrading fungi, which reflects the selective capacity of the studied microorganism to degrade either lignin or cellulose (Soloviev et al., 1986). The data presented in Table 3 showed that during cultivation on a solid substrate, the majority of fungi consumed lignin and cellulose in equal amounts, because the index of xylolysis was around 0.5 , regardless of the medium and time of cultivation. In other words, the summarized activities of ligninolytic and cellulolytic enzymes in the studied strains were similar or included nonenzymatic stages that contributed to the fermentation processes, providing high ligninolytic and cellulolytic potential of basidiomycetes. $T$. hirsuta strain sample was characterized by the lowest Ic (0.42), i.e., this fungi exerted the highest selectivity to lignin.

The analysis of laccase activity and plant substrate lignin mineralization rate indicates the absence of a direct correlation between the studied parameters. It can be explained by the significant increase of laccase synthesis during the first 18 days of cultivation due to copper ions presence that induces enzymatic biosynthesis (Xu, 1999). The amount of the synthesized laccase could significantly exceed the amount required for lignin-carbohydrate complex degradation. However, the high level of enzymatic activity during further fermentation, when the active inducer runs out, confirms the importance of laccase in delignification processes.

\section{CONCLUSIONS:}

The obtained data analysis allowed the authors to conclude that during solid-phase cultivation on plant substrate, the key ligninolytic enzyme in T.maxima and T.hirsuta fungi was laccase. The research data showed that the studied strains of basidium fungi had the highest plant substrate delignification activity and utilized lignin and cellulose equally well (Table 3 ). The obtained results agree with other research data on the role of Pycnoporus cinnabarinus basidiomycete laccase in lignin degradation (Eggert et al., 1997).

Comparison of the data presented in Table 4 showed that during solid-phase cultivation lignin was degraded by the fungi more intensively than during surface liquid-phase cultivation. This was associated with direct contact of fungi hypha with straw, which added the mechanical stage of biotransformation and straw processing by low molecular compounds in radical form, which were known to "process" solid substrate. Besides, direct contact of fungi with straw surface contributed to the more efficient interaction between the synthesized ligninolytic enzymes and lignocellulotic material.

Hence, the obtained data confirmed that there were different mechanisms of lignocellulose material biotransformation during different methods of cultivation. Ligninolytic enzymatic complex biosynthesis was more effective during the cultivation of basidiomycetes on a solid substrate, i.e., in the conditions that modeled their natural life circle. It was concluded that there was no correlation between the level of production and activity of basidiomycetes ligninolytic enzymes, produced in artificial medium and during liquid-phase cultivation, and the degradation efficiency of lignocellulose substrate in natural conditions (during solidphase cultivation). Taking into account all the above-mentioned data, T. Hirsuta strain was selected by the authors for the development of a 
biological product that accelerates biodegradation of hard degrading components of agricultural wastes. This strained expressed high degrading activity in processing both lignin and cellulose.

\section{REFERENCES:}

1. Babitskaya, V. G.; Fungi producers of physiologically active substances on lignocellulose: biology and cultivation, PhD thesis, Institute of Microiology AN BSSR: Minsk, 1991.

2. Bondartseva, M. A.; Modern fungi ecomorphology, Mycology in Russia. Second conference thesis reports of Russian mycologists 2008, 2, 220.

3. Cariello, M. E.; Castaneda, L.; Riobo, I., Gonzalez, J. R. C.; Endogenous microorganisms inoculant to speed up the composting process of urban swage sludge, Suelo Nutr. Veg. 2007, 7(3), 26.

4. Chichkin, A.; Apart from milk and meat. Processing of animal production wastes cuts the costs in agricultural business, Rossiiskaya Bizness-gazeta, 18 August 2009, 715(31).

5. Compost maturity index, California Compost Quality Council, 19375 Lake City Road, Nevada City, CA 95959, June 2001. Available at: www.ccqc.org. Accessed on 25/12/2018.

6. Eggert, C.; Temp, U.; Eriksson, K.-E. L.; Laccase is essential for lignin degradation by white-rot fungus Pycnoporus cinnabarinus, FEBS Letters 1997, 407, 89.

7. Ernakova, A. I.; Plants research methods, Kolos: Leningrad, 1972.

8. Ernst, L.; Zlochevskiy, F.; Erastov, G.; Processing of animal and poultry production wastes, Available at: http://www.webpticeprom.ru/ru/articlesprocessing waste.html?pagelD=1177395301 - 2010 . Accessed on 25/12/2018.

9. Fang, M.; Wong, M. H.; Wong, J. W. C.; Digestion activity of thermophilic bacteria isolated from ash-amended sewage sludge compost, Water Air Soil Pollut. 2001, 126, 1.

10. Galliano, H.; Gas, G.; Seris, J. L.; Boudet,
A. M.; Lignin degradation by Rigidoporus lignosus involves synergistic action of two oxidizing enzymes: Mn peroxidase and laccase, Enzyme Microbiol. Technol. 1991, 13, 478.

11. Golovleva, L. A.; Leontievskiy, A. A.; Lignin biodegradation, Microbiology achievements 1990, 24, 128.

12. Guoxue, Li; Zhang, F.; Sun, Y.; Wong, J. W. C.; Fang, M.; Chemical evaluation of sewage composting as mature indicator for composting process, Water Air Soil Sludge Pollut. 2001, 132, 333.

13. Kulikova, N. A.; Kholodov, V. A.; Lebedeva, G. F.; Perminova, I. V.; Bioassay with humics: a statistical approach to data collection; Frimmel, F. H.; Abbt-Braun, G., eds., Humic substances - linking structure to functions, Proceedings of the 13th Meeting of the International Humic Substances Society, July 30 to August 4 2006, 441.

14. Leonowicz, A.; Grzywnowicz, K.; Enzyme Microbial Technol. 1981, 3, 55.

15. Marr, C. D.; Mycotaxon. 1979, 9, 244.

16. Menotta, M.; Gioacchini, A. M.; Amicucci, A.; Buffalini, M.; Sisti, D.; Stocchi, V.; Headspace solid-phase microextraction with gas chromatography and mass spectrometry in the investigation of volatile organic compounds in an ectomycorrhizae synthesis system, Rapid Communications in Mass Spectrometry 2004, 18, 206.

17. Morisaki, N.; Phae, C. G.; Nakasaki, K.; Shoda, M.; Kubota, H.; Nitrogen transformation during thermophilic composting, J. Ferment. Bioeng. 1989, 67, 57.

18. Orlov, D. S.; Grishina, L. A.; Eroshicheva, N. L.; Practical tasks for humus Biochemistry, MSU: Moscow, 1969.

19. Paszczynski, A.; Crawford, R. L.; Huynh, V.-B.; Methods Enzymol. 1988, 161, 264.

20. Sinitsyn, A. P.; Bioconvesion of lignocellulose materials, Nauka: Moscow, 1995.

21. Soloviev, V. A.; Malysheva, O. N.; Maleva, I. L.; Saplina, V. I.; Chemical composition alterations under lignin degrading action 
of fungi, Woods chemistry 1986, 6, 94.

22. Stepanova, E. V.; Koroleva, O. V.; Vasilchenko, L. G.; Karapetyan, K. N.; Landesman, E. O.; Yavmetdinov, I. S.; Kozlov, I. P.; Rabinovich, M. L.; Degradation of oats straw during liquidphase and solid-phase cultivation, Applied Biochemistry and Microbiology 2003, 39(1), 74.

23. Tuor, U.; Winterhalter, K.; Fiechter, A.; Enzymes of white-rot fungi in lignin degradation and ecological determinants for wood decay, J. of Biotechnology 1995, $41,1$.
24. Vasilchenko, L. G.; Karapetyan, K. N.; Yachkova, S. Ch.; Zernova, E. S.; Rabinovich, M. L.; Llignin-carbohydrate substrate degradation by soil fungi producers of laccase and cellulobiosodehydrogenases, Applied biochemistry and microbiology 2004, 40(1), 51.

25. Xu, F.; Laccase. Flickinger, M. C.; Drew, S. W.; Encyclopedia of bioprocess technology: fermentation, biocatalysis, bioseparation, John Wiley \& Sons, Inc., 1999. 
Table 1. Maximal level of enzyme activity during superficial cultivation on different nutrient media in the absence of (control) and presence of straw (test)

\begin{tabular}{|c|c|c|c|c|c|c|c|c|c|}
\hline Enzyme & & 1 & 2 & 3 & 4 & 5 & 6 & 7 & 8 \\
\hline \multirow{2}{*}{ Laccase } & control & 2.86 & 2.04 & 4.9 & 2.08 & 0.036 & 0.018 & 0.012 & 0.027 \\
\hline & test & 1.34 & 7.54 & 1.7 & 0.88 & 7.03 & 4.2 & 0.33 & 0.033 \\
\hline \multirow{2}{*}{ Peroxidase } & control & 1.51 & 1.07 & 70.88 & 94.13 & 0 & 0.62 & 0.02 & 1.51 \\
\hline & test & 0.99 & 18.41 & 14.4 & 83.00 & 114.06 & 165.22 & 1.35 & 0.86 \\
\hline \multirow{2}{*}{ Polyfunctionl peroxidase } & control & 116.29 & 5.08 & 16.6 & $-*$ & 0 & 0.1 & 0.036 & 1.51 \\
\hline & test & 3.08 & 9.05 & 4.14 & $-*$ & 27.08 & 108.96 & 0.22 & 3.18 \\
\hline \multirow{2}{*}{ Lignin peroxidase } & control & 0.002 & 0.009 & 0.01 & 0.04 & 0.001 & 0.005 & 0.01 & $-*$ \\
\hline & test & 0.07 & 0.07 & 4.25 & 0.54 & 0.046 & 0.021 & 0.27 & $-*$ \\
\hline \multirow{2}{*}{ Aryl-alcohol oxidase } & control & 0.0028 & 0.014 & $-*$ & 0.52 & $-*$ & $-*$ & $-*$ & $-*$ \\
\hline & test & 0.045 & 0.074 & $-*$ & 0.04 & $-^{*}$ & $-{ }^{*}$ & $-*$ & $-{ }^{*}$ \\
\hline \multicolumn{10}{|c|}{1 - Coriolopsis caperata } \\
\hline \multicolumn{10}{|c|}{2 - Pleurotus pulmonarius } \\
\hline \multicolumn{10}{|c|}{ 3-Steccherinum murashkinskyi } \\
\hline \multicolumn{10}{|l|}{4 - Trametes hirsuta } \\
\hline \multicolumn{10}{|c|}{$5-$ Byssomerulius avellaneus } \\
\hline \multicolumn{10}{|c|}{6 - Trametes versicolor } \\
\hline \multicolumn{10}{|c|}{ 7- Irpicodon pendulus } \\
\hline \multicolumn{10}{|l|}{8 - Xerula radicata } \\
\hline
\end{tabular}

Mean discrepancy does not exceed $10 \%$, mean of 9 experiments

$-^{*}$ - measurements were not made 
Table 2. Oat straw composition during surface cultivation in liquid medium ${ }^{\star *}$

\begin{tabular}{|c|c|c|c|c|c|c|c|}
\hline Strain & $\begin{array}{l}\text { Time, } \\
\text { days }\end{array}$ & $\begin{array}{c}\text { Hemi- } \\
\text { cellulose } \\
\text { reduction, } \\
\%\end{array}$ & $\begin{array}{c}\text { Cellulose } \\
\text { reduction } \\
\%\end{array}$ & $\begin{array}{l}\text { Lignin } \\
\text { reduction } \\
\text {, \% }\end{array}$ & $\begin{array}{c}\text { Straw } \\
\text { reduction } \\
, \%\end{array}$ & $\begin{array}{l}I C=C / \\
(C+L)\end{array}$ & $\begin{array}{c}\text { Ic } \\
\text { (mean) }\end{array}$ \\
\hline Pleurotus & 29 & 4.7 & 35.9 & 15.5 & 12.1 & 0.70 & \multirow{2}{*}{0.64} \\
\hline pulmonarius & 47 & 25.3 & 38.0 & 21.6 & 14.4 & 0.57 & \\
\hline Coriolopsis & 29 & 10.9 & 31.5 & 18.5 & 12.0 & 0.67 & \multirow{2}{*}{0.61} \\
\hline caperata & 47 & 38.0 & 38.3 & 22.7 & 14.6 & 0.54 & \\
\hline Steccherinum & 29 & 33.0 & 36.9 & 16.8 & 12.8 & 0.82 & \multirow{2}{*}{0.82} \\
\hline muraskinskyi & 47 & 34.9 & 36.2 & 20.1 & 13.5 & 0.81 & \\
\hline Xerula radicata & 47 & 25.3 & 18.3 & 5.3 & 6.3 & 0.80 & 0.80 \\
\hline Byssomerulius & 29 & 40.7 & 16.1 & 9.6 & 12.3 & 0.75 & \multirow{2}{*}{0.68} \\
\hline avellaneus & 47 & 47.7 & 24.9 & 12.9 & 13.0 & 0.62 & \\
\hline Trametes & 29 & 34.1 & 10.6 & 4.2 & 5.5 & 0.71 & \multirow{2}{*}{0.67} \\
\hline versicolor & 47 & 37.6 & 24.0 & 3.6 & 12.3 & 0.64 & \\
\hline Irpicodon & 29 & 37.1 & 8.4 & 5.9 & 10.4 & 0.61 & \multirow{2}{*}{0.59} \\
\hline pendulus & 47 & 38.7 & 9.3 & 6.2 & 11.4 & 0.57 & \\
\hline Trametes hirsuta & 29 & 23.1 & 32.5 & 23.2 & 12.4 & 0.62 & \multirow{2}{*}{0.65} \\
\hline & 47 & 35.2 & 39.8 & 23.4 & 14.7 & 0.67 & \\
\hline Trametes & 29 & 10.8 & 27.1 & 7.5 & 8.4 & 0.78 & \multirow{2}{*}{0.80} \\
\hline maxima & 47 & 34.4 & 29.4 & 8.0 & 11.5 & 0.82 & \\
\hline
\end{tabular}

*Measurement error did not exceed 15\%, mean of the 3 tests.

${ }^{*}$ Nylon net was used during the tests to prevent fungi from growing into the straw. 
Table 3.The analysis of straw components reduction and fungi biomass during solid-phase fermentation of the studied basidiomycetes* (moisture content 90\%)

\begin{tabular}{|c|c|c|c|c|c|c|c|c|}
\hline Strain & $\begin{array}{l}\text { Time, } \\
\text { days }\end{array}$ & $\begin{array}{c}\text { Hemicell } \\
\text { ulose } \\
\text { reduction } \\
\text {, \% }\end{array}$ & $\begin{array}{c}\text { Cellulose } \\
\text { reduction } \\
, \%\end{array}$ & $\begin{array}{c}\text { Lignin } \\
\text { reduction } \\
\text {, \% }\end{array}$ & $\begin{array}{c}\text { Water } \\
\text { soluble } \\
\text { celluloses } \\
\text { reduction, \% }\end{array}$ & $\begin{array}{c}\text { Straw } \\
\text { mass } \\
\text { reduction } \\
, \%\end{array}$ & $I_{c}$ & $I_{c}$ (mean) \\
\hline $\begin{array}{c}\text { Pleurotus } \\
\text { pulmonarius }\end{array}$ & $\begin{array}{l}29 \\
47\end{array}$ & $\begin{array}{l}64.0 \\
63.9\end{array}$ & $\begin{array}{l}24.0 \\
51.6\end{array}$ & $\begin{array}{l}24.2 \\
35.9\end{array}$ & $\begin{array}{l}15.4 \\
45.3\end{array}$ & $\begin{array}{l}26.7 \\
31.6\end{array}$ & $\begin{array}{l}0.49 \\
0.47\end{array}$ & 0.48 \\
\hline $\begin{array}{c}\text { Coriolopsis } \\
\text { caperata }\end{array}$ & $\begin{array}{l}29 \\
47\end{array}$ & $\begin{array}{l}58.7 \\
43.2\end{array}$ & $\begin{array}{l}24.6 \\
49.1\end{array}$ & $\begin{array}{l}24.4 \\
31.9\end{array}$ & $\begin{array}{l}53.6 \\
54.7\end{array}$ & $\begin{array}{l}21.1 \\
32.2\end{array}$ & $\begin{array}{l}0.51 \\
0.49\end{array}$ & 0.50 \\
\hline $\begin{array}{l}\text { Steccherinum } \\
\text { muraskinskyi }\end{array}$ & 29 & $\begin{array}{l}49.9 \\
48.4\end{array}$ & $\begin{array}{l}26.9 \\
49.8\end{array}$ & $\begin{array}{l}22.7 \\
32.2\end{array}$ & $\begin{array}{l}49.6 \\
53.5\end{array}$ & $\begin{array}{l}26.0 \\
29.5\end{array}$ & $\begin{array}{l}0.48 \\
0.50\end{array}$ & 0.49 \\
\hline $\begin{array}{l}\text { Xerula } \\
\text { radicata }\end{array}$ & $\begin{array}{l}29 \\
47\end{array}$ & $\begin{array}{l}69.3 \\
66.6\end{array}$ & $\begin{array}{l}15.1 \\
10.7\end{array}$ & $\begin{array}{l}10.5 \\
11.5\end{array}$ & $\begin{array}{l}63.5 \\
60.1\end{array}$ & $\begin{array}{l}10.3 \\
18.1\end{array}$ & $\begin{array}{l}0.48 \\
0.52\end{array}$ & 0.5 \\
\hline $\begin{array}{c}\text { Byssomerulius } \\
\text { avellaneus }\end{array}$ & $\begin{array}{l}29 \\
47\end{array}$ & $\begin{array}{l}22.8 \\
60.0\end{array}$ & $\begin{array}{l}43.2 \\
50.8\end{array}$ & $\begin{array}{l}26.3 \\
30.5\end{array}$ & $\begin{array}{l}58.0 \\
39.5\end{array}$ & $\begin{array}{l}24.0 \\
25.8\end{array}$ & $\begin{array}{l}0.48 \\
0.50\end{array}$ & 0.49 \\
\hline $\begin{array}{l}\text { Trametes } \\
\text { versicolor }\end{array}$ & $\begin{array}{l}29 \\
47\end{array}$ & $\begin{array}{l}27.5 \\
52.0\end{array}$ & $\begin{array}{l}4.1 \\
6.6\end{array}$ & $\begin{array}{l}5.5 \\
8.7\end{array}$ & $\begin{array}{l}98.9 \\
87.3\end{array}$ & $\begin{array}{l}6.9 \\
8.3\end{array}$ & $\begin{array}{l}0.49 \\
0.48\end{array}$ & 0.49 \\
\hline $\begin{array}{c}\text { Trametes } \\
\text { hirsuta }\end{array}$ & 47 & $\begin{array}{l}21.1 \\
38.9\end{array}$ & $\begin{array}{l}28.1 \\
53.7\end{array}$ & $\begin{array}{l}28.6 \\
38.9\end{array}$ & $\begin{array}{l}22.2 \\
53.3\end{array}$ & $\begin{array}{l}28.6 \\
31.8\end{array}$ & $\begin{array}{l}0.42 \\
0.50\end{array}$ & 0.47 \\
\hline $\begin{array}{c}\text { Trametes } \\
\text { maxima }\end{array}$ & 47 & $\begin{array}{l}17.9 \\
38.9\end{array}$ & $\begin{array}{l}53.8 \\
52.5\end{array}$ & $\begin{array}{l}23.7 \\
35.4\end{array}$ & $\begin{array}{l}44.4 \\
61.1\end{array}$ & $\begin{array}{l}27.4 \\
32.7\end{array}$ & $\begin{array}{l}0.44 \\
0.47\end{array}$ & 0.46 \\
\hline
\end{tabular}

${ }^{*}$ Measurement error did not exceed 15\%, mean of the 3 tests. 


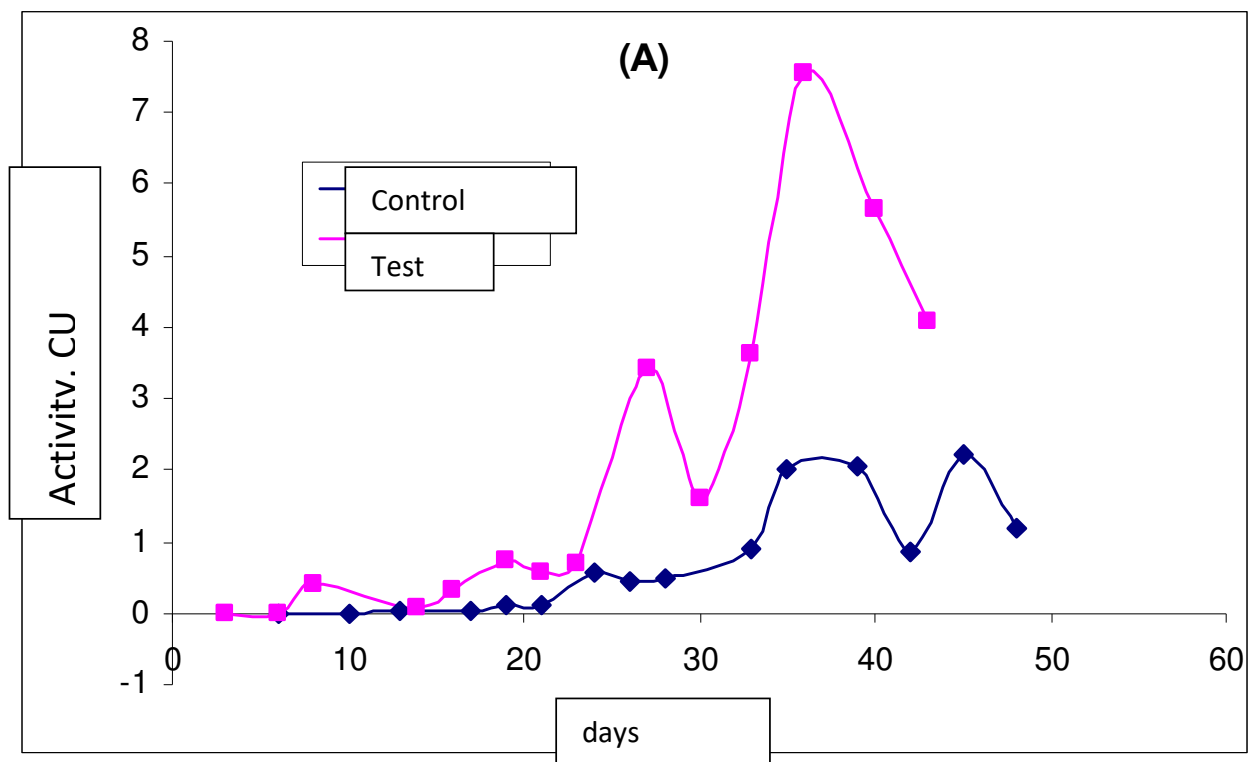

Figure 1. Laccase dynamics activity during surface cultivation of Pleurotus pulmonarius on straw containing medium

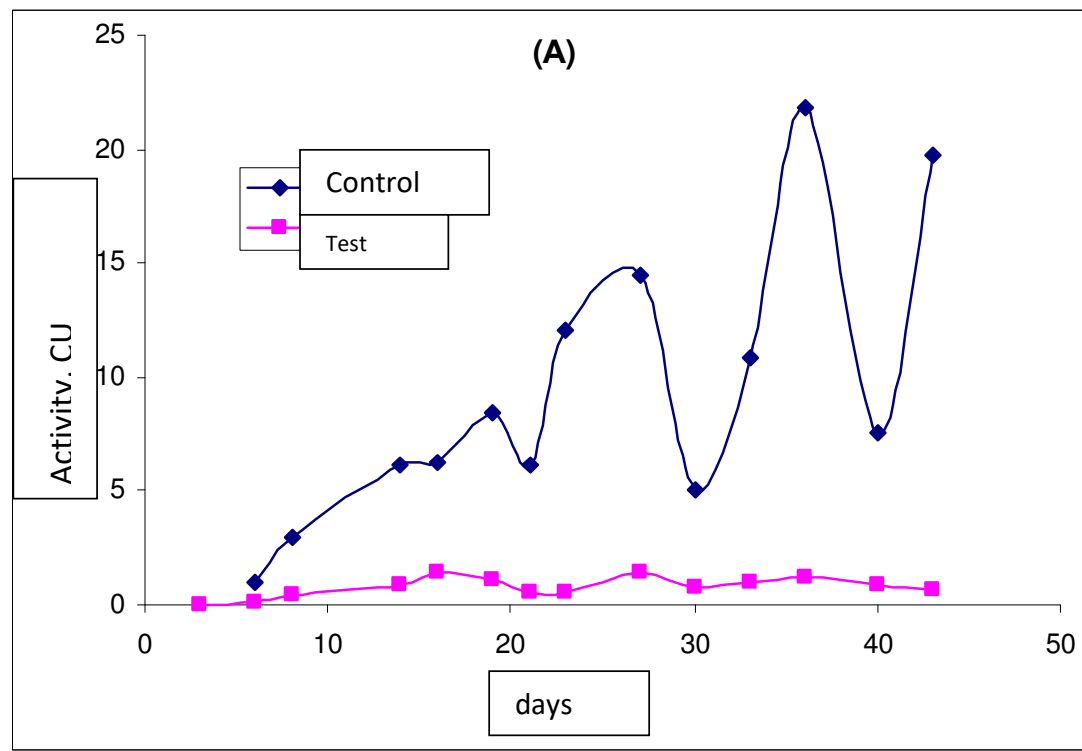

Figure 2. Dynamics of laccase activity of Coriolopsis caperata during surface cultivation 


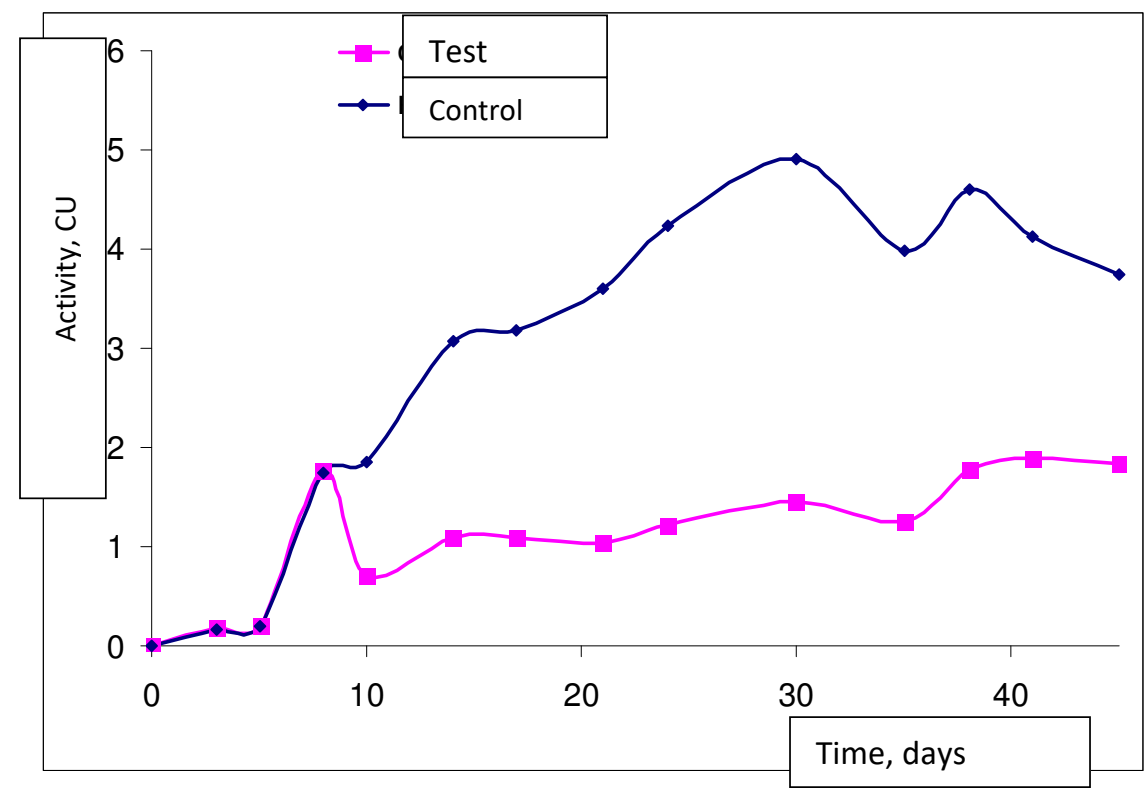

Figure 3. Dynamics of laccase activity of Steccherinum murashkinskyi during liquid-phase cultivation

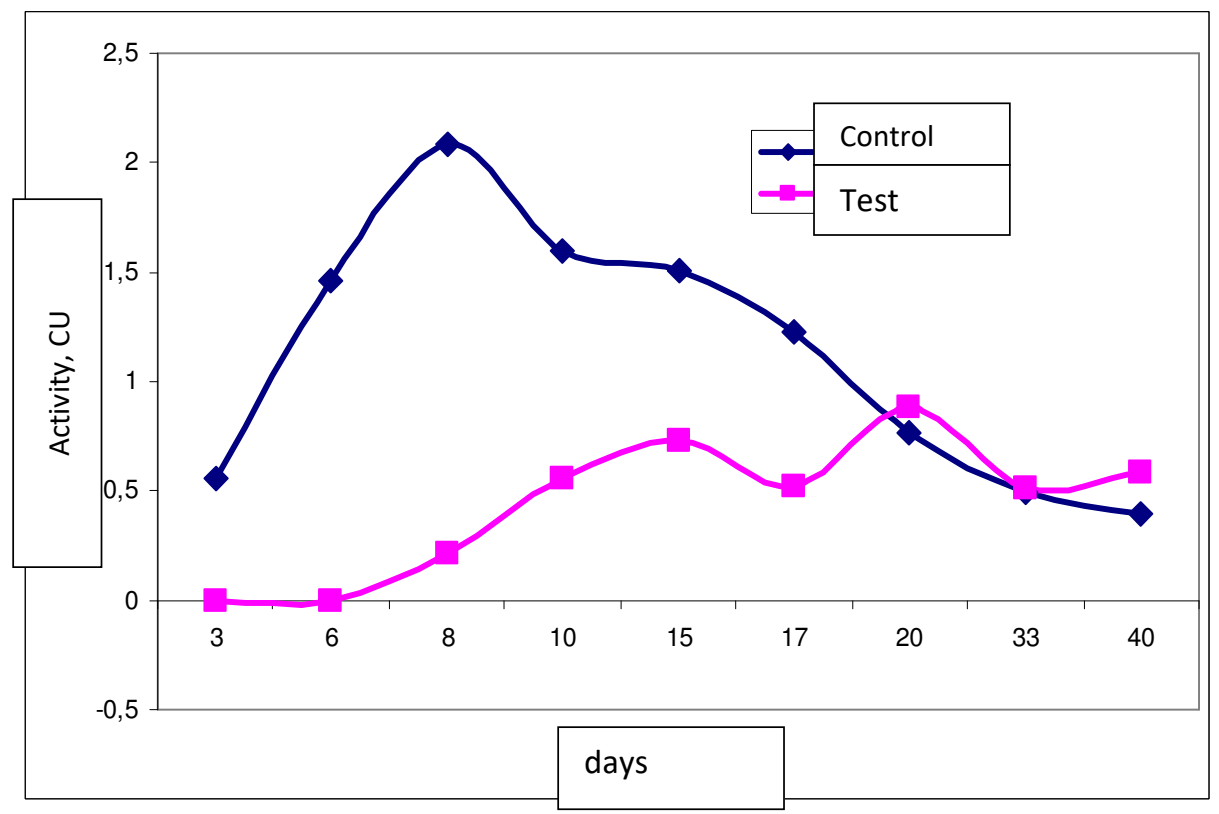

Figure 4. Dynamics of laccase activity of Trametes hirsuta during liquid-phase cultivation 


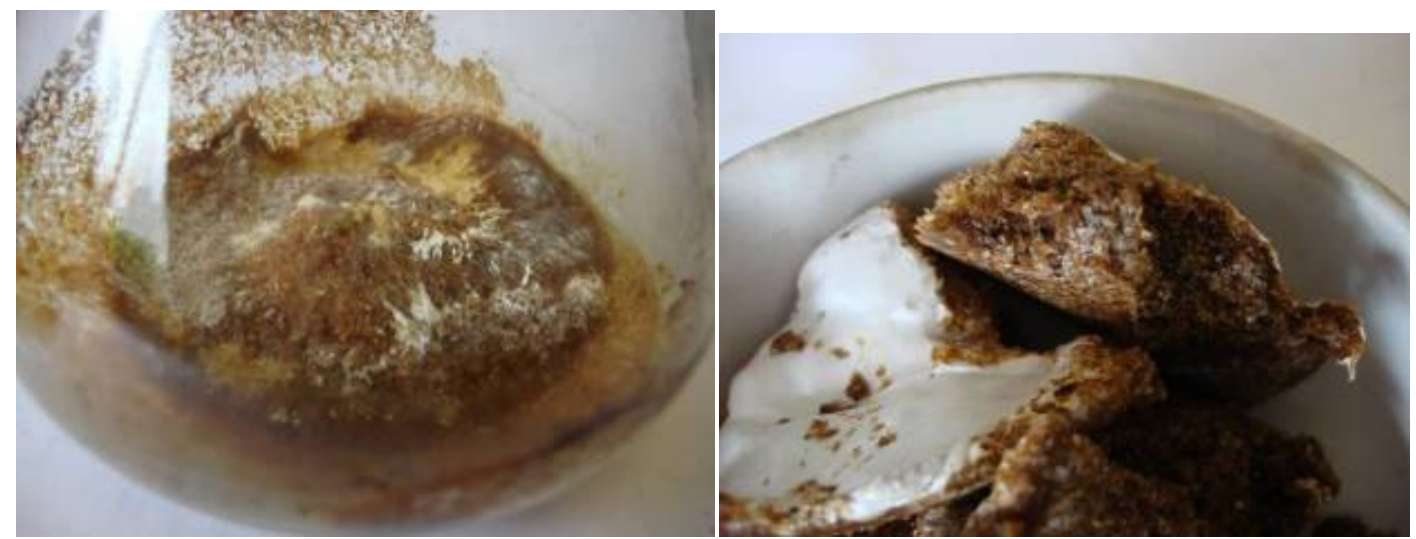

Figure 5. Steccherinum murashkinskyi solid-phase cultivation on straw containing medium

PERIÓDICO TCHÊ QUÍMICA•www.periodico.tchequimica.com• Vol. 16 N. 31.

• ISSN 1806-0374 (impresso) • ISSN 1806-9827 (CD-ROM) • ISSN 2179-0302 (meio eletrônico) (c) 2019. Porto Alegre, RS. Brasil

The Periódico Tchê Química (ISSN: 1806-0374; 2179-0302) is an open-access journal since 2004. Journal DOI: 10.52571/PTQ. http://www.tchequimica.com. This text was introduced in this file in 2021 for compliance reasons.

(C) The Author(s)

OPEN ACCESS. This article is licensed under a Creative Commons Attribution 4.0 (CC BY 4.0) International License, which permits use, sharing, adaptation, distribution, and reproduction in any medium or format, as long as you give appropriate credit to the original author(s) and the source, provide a link to the Creative Commons license, and indicate if changes were made. The images or other third-party material in this article are included in the article 's Creative Commons license unless indicated otherwise in a credit line to the material . If material is not included in the article's Creative Commons license and your intended use is not permitted by statutory regulation or exceeds the permitted use, you will need to obtain permission directly from the copyright holder. To view a copy of this license, visit http://creativecommons.org/licenses/by/4.0/. 